\title{
Social inequality and mortality trend of diabetes
}

\author{
Oswaldo Medina-Gómez',2 and Ismael Seth Medina-Reyes ${ }^{3}$
}

${ }^{1}$ National School of Nursing and Obstetrics, Universidad Nacional Autónoma de México; '2Department of Epidemiology, Family Medicine Unit 15, Instituto Mexicano del Seguro Social (IMSS); ${ }^{3}$ Coordinatio of Epidemiological Surveillance and Contingency Support, IMSS, Ciudad de México, Mexico

\begin{abstract}
Objective: To identify the trend of national diabetes mortality by level of marginality at the state and municipal levels. Method: A descriptive study was conducted with records of deaths from diabetes in over 20 years from 1990 to 2013. The national mortality rate was calculated standardized by age according to the 2000 world population and the state level 2013 saw the projected naational population by join point analysis for trend analysis was performed. Results: For the general population, the annual percentage change between 1990 and 1996 was 2.2, from 1996 to 2005 was 4.3, and from 2005 to 2013 was 0.1. The largest increase among women occurred between 1998 and 2005 while among men occurred between 1995 and 2006. At the state level was found higher annual percentage change between the towns with the highest degree of marginalization. Conclusions: The mortality of diabetes in women shows a significant decrease since 2004, among men, the mortality with a continuous upward trend, consistent with the trend that the disease has had in recent years.
\end{abstract}

KEY WORDS: Health inequity. Social marginalization. Diabetes. Mortality.

\section{Introduction}

Type 2 diabetes mellitus (DM2) is a chronic condition, the prevalence of which continues to increase in the entire world. World-wide diabetes prevalence estimate in 2000 was $2.8 \%$, and it is expected to be $4.4 \%$ by 2030 , which represents nearly 165 million people who will be diagnosed with this condition'.

In 2010, the region with the highest prevalence of DM2 was North America, followed by Eastern Europe and southern Asia. That same year, Mexico occupied the tenth place in the world with regard to the number of adults with diabetes, and it is expected to rise to the seventh place ${ }^{2}$.

The demographic change owing to the increase in the number of people older than 65 years has contributed to the increase in the prevalence of diabetes in the entire world ${ }^{3}$.
Although the existence has been proposed of genetic regulation between lipid metabolism, insulin action and resistance, as well as with an increase in inflammatory markers, such as $\mathrm{C}$-reactive protein and interleukin 6, which biologically contribute to the predisposition of individuals for developing diabetes sometime in life ${ }^{4-7}$, it is their social determinants that establish the differences in incidence, prevalence and mortality of the disease in different social groups ${ }^{8-11}$. In the entire world, socioeconomic conditions such as social status, education and income have been identified as important determinants that contribute to an increase in diabetes-related mortality ${ }^{11-14}$.

The impact of the disease is expressed in a differentiated way between social groups. There is evidence that incidence rates have been mainly increasing among those who live in low-income communities, especially among poor women ${ }^{15-17}$.

\footnotetext{
Correspondence:

Oswaldo Medina-Gómez

Ermita Iztapalapa, 411

Col. Coyoacán, Del. Prado Churubusco

C.P. 04320, Ciudad de México, México

E-mail: epired@gmail.com
}

Date of reception: 01-10-2016

Date of acceptance: 03-11-2016

DOI://dx.doi.org/10.24875/GMM.M18000081
Gac Med Mex. 2017;153:712-717

Contents available at PubMed www.gacetamedicademexico.com 
Table 1. Age-adjusted type 2 diabetes mellitus mortality rate by State of residence, Mexico, 1990-2013

\begin{tabular}{|c|c|c|c|c|c|c|}
\hline \multirow[t]{2}{*}{ State } & \multicolumn{2}{|c|}{1990} & \multicolumn{2}{|c|}{2000} & \multicolumn{2}{|c|}{2013} \\
\hline & MR & $95 \% \mathrm{Cl}$ & MR & $95 \% \mathrm{Cl}$ & MR & $95 \% \mathrm{Cl}$ \\
\hline Aguascalientes & 82.5 & $72.02-94.4$ & 95.3 & $86.1-105.2$ & 114.2 & $106.2-122.6$ \\
\hline Baja California & 123.3 & $113.2-134.2$ & 120.6 & $113.5-128.0$ & 108.9 & $103.9-114.0$ \\
\hline Baja California Sur & 94.5 & $77.2-114.4$ & 100.9 & $86.4-117.2$ & 95.6 & $85.2-106.9$ \\
\hline Campeche & 44.1 & $36.1-53.4$ & 61.2 & $53.0-70.4$ & 110.7 & $101.7-120.3$ \\
\hline Coahuila & 133.3 & $124.5-142.7$ & 130.6 & $123.7-137.8$ & 131.5 & $126.1-136.9$ \\
\hline Colima & 63.3 & $52.9-75.4$ & 80.9 & $70.7-92.2$ & 126.3 & $116.0-137.4$ \\
\hline Chiapas & 27.5 & $24.7-30.5$ & 63.2 & $59.4-67.1$ & 100.9 & $97.0-104.9$ \\
\hline Chihuahua & 134.9 & $126.8-143.4$ & 98.0 & $92.7-103.6$ & 104.4 & $100.1-108.7$ \\
\hline Distrito Federal & 142.1 & $142.1-146.7$ & 127.8 & $124.7-131.1$ & 105.6 & 103.2-108 \\
\hline Durango & 95.1 & $86.6-104.3$ & 89.8 & 83-97.2 & 103.4 & $97.5-109.7$ \\
\hline Guanajuato & 70.0 & $66.1-74.2$ & 106.3 & $102.2-110.5$ & 137.9 & $134-141.9$ \\
\hline Guerrero & 26.6 & $24-29.5$ & 53.8 & $50.3-57.5$ & 108.7 & $104.4-113.2$ \\
\hline Hidalgo & 46.7 & $42.5-51.1$ & 72.1 & $67.4-77$ & 102.3 & $97.6-107$ \\
\hline Jalisco & 77.1 & $73.6-80.7$ & 97.0 & $93.7-100.5$ & 111.6 & $108.6-114.6$ \\
\hline México & 32.7 & $31.5-34$ & 121.7 & $118.7-124.9$ & 134.8 & $132.4-135.5$ \\
\hline Michoacán & 49.6 & $46.5-53$ & 84.6 & 80.9-88.5 & 126.2 & $126.2-130.2$ \\
\hline Morelos & 60.7 & $54.7-67.3$ & 86.5 & $80.4-93.1$ & 122.3 & 116.3-128.4 \\
\hline Nayarit & 58.6 & $51.5-66.4$ & 71.4 & 64.4-79 & 74.2 & $68.3-80.5$ \\
\hline Nuevo León & 95.7 & $90-101.9$ & 89.3 & $84.9-93.8$ & 99.8 & $96.3-103.4$ \\
\hline Oaxaca & 29.0 & $28.7-26.2$ & 58.1 & $55.2-52$ & 117.1 & $100.8-97$ \\
\hline Puebla & 61.3 & $57.9-64.8$ & 101.1 & $97.2-105$ & 144.6 & $140.7-148.5$ \\
\hline Querétaro & 62.5 & $55.2-70.5$ & 92.9 & $85.5-100.7$ & 107.0 & $100.7-113.5$ \\
\hline Quintana Roo & 41.2 & $30.6-54.3$ & 57.4 & $48-68.3$ & 120.7 & $111.3-130.9$ \\
\hline San Luis Potosí & 51.9 & $47.5-56.5$ & 70.8 & $66.2-75.6$ & 99.6 & $95.1-104.4$ \\
\hline Sinaloa & 68.6 & $63-74.6$ & 80.4 & $75.4-85.7$ & 81.8 & $77.8-86$ \\
\hline Sonora & 100.5 & $92.2-109.6$ & 97.8 & $91.7-104.3$ & 98.3 & $93.6-103.1$ \\
\hline Tabasco & 41.0 & $36.1-46.3$ & 87.9 & $81.6-94.6$ & 154.0 & $147.2-161$ \\
\hline Tamaulipas & 101.8 & $95.2-108.7$ & 108.9 & $103.4-114.8$ & 120.2 & $115.6-124.9$ \\
\hline Tlaxcala & 66.6 & $58.4-75.7$ & 106.1 & $97.2-115.7$ & 158.7 & $149.6-168.2$ \\
\hline Veracruz & 54.5 & $51.9-57.1$ & 82.6 & $79.8-85.5$ & 130.4 & $127.4-133.4$ \\
\hline Yucatán & 61.1 & $55-67.9$ & 65.6 & $60.5-71$ & 89.9 & 84.9-95 \\
\hline Zacatecas & 38.8 & $34-44.2$ & 67.6 & 61.9-73.6 & 97.9 & $92-104.1$ \\
\hline
\end{tabular}

In Mexico, DM2 is the leading cause of mortal- death, of years lost due to premature death, of ity, and it has shown a progressive increase over years lived with disability and of healthy life-years the past few years ${ }^{18}$, and it is the main cause of lost $^{19}$. 


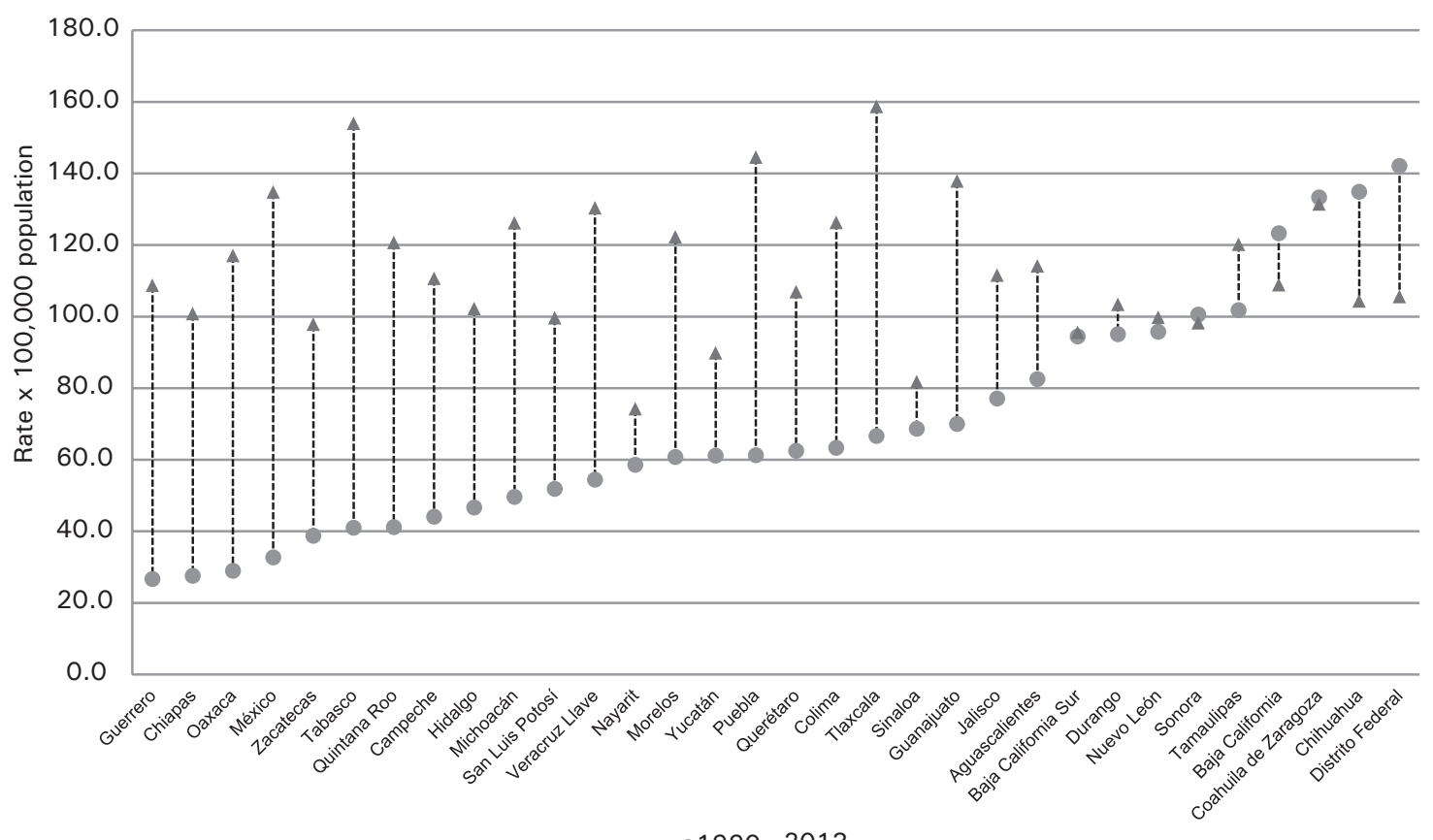

$\bullet 1990 \triangle 2013$

Figure 1. Mortality rate adjusted by State, Mexico, 1990 and 2013.

Different efforts have been made in Mexico with regard to prevention and health promotion ${ }^{20-22}$, and this is why the purpose of the present study was to analyze the changes in the trends of mortality of DM2 in Mexico according to the level of marginality during the 1990-2013 period, using the joinpoint regression model.

\section{Method}

A descriptive study was carried out based on secondary information sources corresponding to the 1990-2013 period for the 31 States and the Federal District of the country. All deaths registered in the Health Information System of the Ministry of Health of Mexico during the analyzed period, with basic cause of death registered with the E11-E14 codes of the International Classification of Diseases, $10^{\text {th }}$ revision (ICD-10), in people older than 20 years, as well as deaths reported by the Directorate General of Health Information, were studied.

DM2 crude mortality rate was calculated as the number of deaths that occur divided by the number of people in a given year according to the registry by the National Council of Population (CONAPO - Consejo Nacional de Población), and an adjustment of rates to the national context was made by direct age-method using 2010 world population reported by the World
Health Organization. For the States, the reference population reported for the country for 2013 was considered.

The statistical package Joinpoint Regression Program 4.2.0.2 was used for the diabetes mortality-adjusted rates trend analysis at the national and State levels in order to identify and describe the occurrence of changes in a period of time through the tendency of data. For the construction of the model, log-transformation was chosen. The program selects the final model using a permutation test and the Bayesian information criterion, and reports the minimum and maximum number of joinpoints, pointing at the most parsimonious model.

The rate of change for each trend is tested to determine if the change is significantly different from zero. Each trend in the model is described as a percentage of annual change (PAC) with a $95 \%$ confidence interval $(\mathrm{Cl})$. If the $95 \% \mathrm{Cl}$ does not contain zero, the PAC is considered to be statistically significant.

Finally, the joinpoint analysis was carried out by gender and by municipal margination degree of the recorded residence in the death certificate, reported by the National Council for Social Development Policy Evaluation (CONEVAL -Consejo Nacional de Evaluación de la Política de Desarrollo Social) for the year 2012. 
Table 2. Type 2 diabetes mortality annual change percentage in the 20 -year old and older population by gender and level of marginality of municipality of residence, Mexico, 1990-2013

\begin{tabular}{|c|c|c|c|c|c|}
\hline Cohort & Reported segments & Period & PAC & $95 \% \mathrm{Cl}$ & $p$ \\
\hline \multirow[t]{3}{*}{ National } & 1 & 1990-1996 & 2.2 & $1.1-3.4$ & $<0.001$ \\
\hline & 2 & 1996-2005 & 4.3 & $3.5-5.0$ & $<0.001$ \\
\hline & 3 & $2005-2013$ & 0.1 & $-0.6-0.8$ & 0.75 \\
\hline \multirow[t]{3}{*}{ Males } & 1 & 1990-1995 & 1.3 & $-1.0-3.6$ & 0.24 \\
\hline & 2 & $1995-2006$ & 4.5 & $4.0-5.1$ & $<0.001$ \\
\hline & 3 & $2006-2013$ & 0.9 & $0.1-1.7$ & 0.02 \\
\hline \multirow[t]{3}{*}{ Females } & 1 & 1990-1998 & 2.2 & $1.2-3.1$ & 0.001 \\
\hline & 2 & $1998-2005$ & 4.4 & $3.2-5.6$ & 0.001 \\
\hline & 3 & 2005-2013 & -0.4 & $-1.0-0.3$ & 0.25 \\
\hline \multicolumn{6}{|c|}{ Level of marginality of the municipality of residence } \\
\hline Very low & 1 & 1990-1994 & 2.7 & $0.3-5.2$ & 0.03 \\
\hline Low & 2 & $1994-2005$ & 6.9 & 6.3-7.5 & $<0.001$ \\
\hline Intermediate & 3 & $2005-2013$ & 2.3 & $1.5-3.1$ & $<0.001$ \\
\hline High & 1 & $1990-2005$ & 7.1 & $6.8-7.5$ & $<0.001$ \\
\hline \multirow[t]{6}{*}{ Very high } & 2 & $2005-2013$ & 4.3 & $3.5-5.2$ & $<0.001$ \\
\hline & 1 & $1990-2004$ & 8.1 & $7.7-8.4$ & $<0.001$ \\
\hline & 2 & $2004-2013$ & 5.0 & $\begin{array}{l}1.1-0.4 \\
4.3-5.7\end{array}$ & $<0.001$ \\
\hline & 1 & 1990-2009 & 8.5 & $8.2-8.8$ & $<0.001$ \\
\hline & 2 & 2009-2013 & 4.8 & $\begin{array}{l}0.7-0.0 \\
1.7-7.9\end{array}$ & 0.004 \\
\hline & 1 & 1990-2013 & 10.6 & $10.2-10.9$ & $<0.001$ \\
\hline
\end{tabular}

95\% Cl: $95 \%$ confidence interval; PAC: percentage of annual change.

\section{Results}

During the analyzed period, 1,279,765 deaths caused by DM2 were reported in 20-year old or older people. Out of these, $46.2 \%(\mathrm{~N}=591,105)$ corresponded to the male and $53.8 \%(\mathrm{~N}=688,660)$ to the female gender; 2016 certificates did not specify the subject gender or age, and were therefore censored from the study.

Age-adjusted DM2 mortality rates by State are described in table 1 . The mortality rates differences from 1990 to 2013 reflect a heterogeneous increase in DM2 mortality rates, with Tabasco standing out with the largest difference (Fig, 1).

In the joinpoint model for the national diabetes mortality trend, three points of change in time were identified. The first period corresponds to 1990-1996, which shows a statistically significant PAC of 2.2; the next change was identified in 1996-2005, with a PAC of 4.3 (95\% Cl: 3.5-5.0; $p<0.01$ ); and the third period corresponds to $2005-2013$, with a PAC of 0.1 (95\% Cl: -0.6-0.8) (Table 2).

In females, PAC in 1990-1998 was $2.2(95 \% \mathrm{Cl}$ : 1.2-3.1); in 1998-2005 it was 4.4 (95\% Cl: 3.2-5.6); and in $2005-2013$ it was -0.4 , with no statistical significance $(p=0.25)$.
In males, PAC in 1990-1995 was $1.3(p=0.24)$; in $1995-2006$ it was 4.5 (95\% Cl: 4.0-5.1); and in 20062013 it was $0.9(95 \% \mathrm{Cl}$; 0.1-1.7).

The joinpoint analysis according to the level of marginality of the municipality of residence reported in the death certificate shows that PAC is increased at all levels; however, it is higher in the municipalities with very high margination $(\mathrm{PAC}=10.6 ; 95 \% \mathrm{Cl}$ : 10.2-10.9), with this encompassing the entire study period (Table 2).

The DM2 mortality rate in the State with the highest index of marginalization (Guerrero) is 1.03-fold higher than in the State with the lowest margination level (Distrito Federal), while the State with the highest proportion of population with income below the wellbeing line (Chiapas) has a mortality rate 1.01-fold higher than the one with best conditions (Nuevo León).

The State with the lowest percentage of access to health services (Puebla) has a DM2 mortality rate 1.3fold higher with regard to the one with the highest access (Campeche).

When the joinpoint analysis was considered for each State, the DM2 mortality increase in the State of Mexico between the years 1990 and 1992 stands out, with this increase being the highest at the State level during the analyzed years (Table 3). 
Gaceta Médica de México. 2017;153

Table 3. Type 2 diabetes mellitus mortality annual change percentage by State, Mexico, 1990-2013

\begin{tabular}{|c|c|c|c|c|c|c|c|c|c|}
\hline & Period & PAC & $95 \% \mathrm{Cl}$ & $p$ & & Period & PAC & $95 \% \mathrm{Cl}$ & $p$ \\
\hline Aguascalientes & $1990-2013$ & 1.5 & $0.8-2.1$ & $<0.001$ & Nayarit & $1990-2010$ & 3.1 & $2.6-3.7$ & $<0.001$ \\
\hline \multirow[t]{3}{*}{ Baja California } & 1990-1993 & -4.6 & $-11.6-3.1$ & 0.22 & & $2010-2013$ & -8.1 & $-17.2-2$ & 0.11 \\
\hline & 1993-2006 & 1 & $0.1-1.9$ & 0.04 & Nuevo León & 1990-1994 & -4.7 & $-10.7-1.7$ & 0.14 \\
\hline & $2006-2013$ & -2 & $-4-0$ & 0.53 & & 1994-2005 & 3.1 & $1.4-4.7$ & $<0.001$ \\
\hline Baja California Sur & 1990-2013 & 0.8 & $0.3-1.3$ & 0.03 & & $2005-2013$ & -1.3 & $-3.5-0.9$ & 0.24 \\
\hline Campeche & $1990-2013$ & 3.9 & $3.4-4.5$ & $<0.001$ & Oaxaca & 1990-2004 & 7.3 & $6.7-7.8$ & $<0.001$ \\
\hline \multirow[t]{3}{*}{ Coahuila } & 1990-1996 & -1.6 & $-3.5-0.4$ & 0.11 & & $2004-2013$ & 3.2 & $2.2-4.2$ & $<0.001$ \\
\hline & 1996-2005 & 3.3 & $2-4.6$ & $<0.001$ & Puebla & 1990-1995 & 1.7 & $-1.1-4.5$ & 0.23 \\
\hline & $2005-2013$ & -2.5 & $-3.8--1.3$ & $<0.001$ & & $1995-2003$ & 7.7 & $5.9-9.5$ & $<0.001$ \\
\hline Colima & $1990-2013$ & 2.9 & $2.5-3.3$ & $<0.001$ & & $2003-2013$ & 1.1 & $0.1-2.1$ & 0.03 \\
\hline \multirow[t]{2}{*}{ Chiapas } & 1990-2002 & 8.5 & $7.7-9.2$ & $<0.001$ & Querétaro & 1990-1996 & 1.2 & $-0.9-3.4$ & 0.23 \\
\hline & 2002-2013 & 3.4 & $2.6-4.2$ & $<0.001$ & & 1996-1999 & 10.2 & $-2.8-24.9$ & 0.12 \\
\hline \multirow[t]{3}{*}{ Chihuahua } & 1990-1992 & -14.6 & $-27.7-0.8$ & 0.06 & & 1999-2008 & 2.4 & $1-3.8$ & 0.002 \\
\hline & $1992-2008$ & 1.5 & $0.8-2.3$ & $<0.001$ & & $2008-2013$ & -1.3 & $-4-1.6$ & 0.30 \\
\hline & 2008-2013 & -3.9 & $-7.4--0.2$ & 0.04 & Quintana Roo & 1990-2013 & 4.5 & $3.8-5.2$ & $<0.001$ \\
\hline \multirow[t]{3}{*}{ Distrito Federal } & 1990-1994 & -4.1 & $-7.5--0.6$ & 0.02 & San Luis Potosí & 1990-1997 & 2.1 & $0.4-3.8$ & 0.02 \\
\hline & $1994-2010$ & 1.1 & $0.6-1.6$ & $<0.001$ & & 1997-2005 & 5.8 & $4-7.5$ & $<0.001$ \\
\hline & 2010-2013 & -8.1 & $-13.2--2.8$ & 0.006 & & $2005-2013$ & 0.4 & $-1-1.7$ & 0.58 \\
\hline \multirow[t]{3}{*}{ Durango } & 1990-2001 & 0.6 & $-0.8-2$ & 0.40 & Sinaloa & 1990-1995 & 0.2 & $-2.5-3$ & 0.88 \\
\hline & $2001-2006$ & 6.7 & $0-13.8$ & 0.05 & & $1995-2003$ & 4.4 & $2.7-6.1$ & $<0.001$ \\
\hline & 2006-2013 & -4.1 & $-6.7--1.5$ & 0.005 & & 2003-2013 & -1.3 & $-2.3--0.4$ & 0.01 \\
\hline \multirow[t]{2}{*}{ Guanajuato } & 1990-2005 & 4.2 & $3.6-4.7$ & $<0.001$ & Sonora & $1990-2013$ & 0.1 & $-0.2-0.5$ & 0.37 \\
\hline & $2005-2013$ & 0.6 & $-0.7-2$ & 0.35 & Tabasco & 1990-2004 & 7 & $5.9-8.1$ & $<0.001$ \\
\hline \multirow[t]{2}{*}{ Guerrero } & 1990-1996 & 9 & 6.4-11.6 & $<0.001$ & & $2004-2013$ & 2.8 & $0.8-4.8$ & 0.009 \\
\hline & 1996-2013 & 5.7 & $5.1-6.2$ & $<0.001$ & Tamaulipas & 1990-1994 & -2.4 & $-5.1-0.3$ & 0.07 \\
\hline \multirow[t]{2}{*}{ Hidalgo } & 1990-2007 & 4.4 & $4-4.8$ & $<0.001$ & & 1994-2003 & 3.2 & $2.2-4.2$ & $<0.001$ \\
\hline & 2007-2013 & 1 & $-0.7-2.7$ & 0.25 & & 2003-2013 & -0.0004 & $-0.7-0.6$ & 0.91 \\
\hline \multirow[t]{2}{*}{ Jalisco } & 1990-2005 & 2.7 & $2.2-3.1$ & $<0.001$ & Tlaxcala & $1990-2013$ & 3.9 & $3.6-4.3$ & $<0.001$ \\
\hline & $2005-2013$ & -0.4 & $-1.5-0.8$ & 0.50 & Veracruz & 1990-1998 & 3.6 & $2.6-4.7$ & $<0.001$ \\
\hline \multirow[t]{2}{*}{ México } & 1990-1992 & 61.2 & $34.8-92.6$ & $<0.001$ & & 1998-2002 & 7.9 & $3.1-12.9$ & 0.003 \\
\hline & 1992-2013 & 1.8 & $1.4-2.3$ & $<0.001$ & & $2002-2013$ & 2.8 & $2.1-3.4$ & $<0.001$ \\
\hline \multirow[t]{2}{*}{ Michoacán } & 1990-2005 & 5.3 & $4.9-5.6$ & $<0.001$ & Yucatán & $1990-2000$ & 0.8 & $-0.3-2$ & 0.15 \\
\hline & 2005-2013 & 2 & $1.1-3$ & $<0.001$ & & $2000-2003$ & 10.8 & $-4.3-28.4$ & 0.15 \\
\hline \multirow[t]{2}{*}{ Morelos } & 1990-2008 & 4.1 & $3.6-4.5$ & $<0.001$ & & $2003-2013$ & $<0.001$ & $-1.1-1.2$ & 0.96 \\
\hline & $2008-2013$ & 0.3 & $-2.9-3.6$ & 0.83 & Zacatecas & $1990-2013$ & 3.5 & $2.7-4.2$ & $<0.001$ \\
\hline
\end{tabular}




\section{Discussion}

Diabetes-related mortality in Mexico affects both genders, which differs from findings in other countries $^{23,24}$. Among females, since the year 2004, mortality-related diabetes shows an important decrease; on the other hand, mortality among males continues with an upward trend, which is consistent with the tendency the disease has had in the past few years ${ }^{25}$.

In the case of diabetes, people who follow an adequate diet have been shown to achieve better metabolic control. However, the control of cardiovascular risk factors is poor in Mexico ${ }^{26}$, which directly impacts on an increase in population mortality.

It is necessary to consider the limitation of using reported deaths, since they are often susceptible to poor quality of registration, mainly because in Mexico there is diabetes over-reporting in death certificates ${ }^{27,28}$.

However, when DM2-related mortality is analyzed with the jointpoint method, trend changes can be studied at the national and State levels, which allows knowing whether modifications are significant, in addition to identifying the heterogeneity of changes in the mortality trends.

The obtained results open new questions about the effectiveness of health policies centered in the individual, and suggest the necessity for further studies to be conducted to analyze the distribution and social determinants, such as access to health services and marginality, among others, which contribute to the patterns of DM2-related mortality change, and that turn out to be large obstacles for the detection, care and prevention of this disease $\mathrm{e}^{29-31}$.

The mortality trends analysis with the joinpoint method is highly useful to monitor changes of a disease over time, which can contribute to the design of new health strategies by enabling the identification of variations in the mortality trends of the disease and the recognition of these changes significance.

\section{References}

1. Zimmet P, Alberti K, Shaw J. Global and societal implications of the diabetes epidemic. Nature. 2001;414:782-7.

2. Shaw JE, Sicree RA, Zimmet PZ. Global estimates of the prevalence of diabetes for 2010 and 2030. Diabetes Res Clin Pract. 2010;87:4-14.

3. Wild S, Roglic G, Green A, et al. Global prevalence of diabetes: estimates for the year 2000 and projections for 2030. Diabetes Care. 2004; 27:1047-53.

4. Emanuelli B, Glondu M, Filloux C, et al. The potential role of SOCS-3 in the interleukin-10-induced desensitization of insulin signaling in pancreatic beta-cells. Diabetes. 2004;53:S97-S103.
5. Muller-Wieland D, Knebel B, Avci A, et al. Insulin-regulated transcription factors: molecular link between insulin resistance and cardiovascular risk factors. Int J Obes Metab Disord. 2001:25(Suppl 1):35-7.

6. Pradhan AD, Manson JE, Rifai N, et al. C-reactive protein, interleukin 6 , and risk of developing type 2 diabetes mellitus. JAMA. 2001;286:327-34.

7. Banerjee M, Saxena M. Interleukin-1 (IL-1) family of cytokines: role in type 2 diabetes. Clin Chim Acta. 2012;413:1163-70.

8. Hsu CC, Lee $\mathrm{CH}$, Wahlqvist ML, et al. Poverty increases type 2 diabetes incidence and inequality of care despite universal health coverage. Diabetes Care. 2012;35:2286-92.

9. Marmot M, Allen JJ. Social determinants of health equity. Am J Public Heatlh. 2014;104(Suppl 4):S517-9.

10. Blas E, Kurup AS. Equity, social determinants and public health programmes.Geneve: World Health Organization; 2010.

11. Espelt A, Arriola L, Borrell C, et al. Socioeconomic position and type 2 diabetes mellitus in Europe 1999-2009: a panorama of inequalities. Curr Diabetes Rev. 2011;7:148-58.

12. Dray-Spira R, Gary-Webb TL, Brancati FL. Educational disparities in mortality among adults with diabetes in the U.S. Diabetes Care. 2010; 33:1200-5.

13. Espelt $A$, Kunst $A E$, Palència $L$, et al. Twenty years of socio-economic inequalities in type 2 diabetes mellitus prevalence in Spain, 1987-2006. Eur J Public Health. 2012;22:765-71.

14. Borrell C, Azlor E, Rodríguez-Sanz M, et al. Trends in socioeconomic mortality inequalities in a southern European urban setting at the turn of the $21^{\text {st }}$ century. J Epidemiol Community Health. 2008;62:258-66.

15. Lee TC, Glynn RJ, Peña JM, et al. Socioeconomic status and incident type 2 diabetes mellitus: data from the Women's Health Study. PLoS One. 2011;6:e27670.

16. Agardh $\mathrm{E}$, Allebeck $\mathrm{P}$, Hallqvist J, et al. Type 2 diabetes incidence and socio-economic position: a systematic review and meta-analysis. Int $\mathrm{J}$ Epidemiol. 2011;40:804-8.

17. Raphael D, Anstice S, Raine K, et al. The social determinants of the incidence and management of type 2 diabetes mellitus: are we prepared to rethink our questions and redirect our research activities? Leadership in Health Services. 2003;16:10-20.

18. Rull JA, Aguilar-Salinas CA, Rojas R, et al. Epidemiology of type 2 diabetes in Mexico. Arch Med Res. 2005;36:188-96.

19. Rodríguez-Abrego G, Escobedo J, Zurita B, et al. Muerte prematura y discapacidad en los derechohabientes del Instituto Mexicano del Seguro Social. Salud Pública Méx. 2007;49:132-43.

20. León-Mazón MA, Arauj-Mendoza GJ, Linos-Vázquez ZZ. Eficacia del programa de educación en diabetes (DiabetIMSS) en los parámetros clínicos y bioquímicos. Rev Med Inst Mex Seguro Soc. 2012;51:74-9.

21. Gutiérrez G, Pérez-Cuevas R, Levy $S$, et al. Strengthening preventive care programs: a permanent challenge for healthcare systems; lessons from PREVENIMSS México. Public Health. 2010;10:417.

22. Instituto Mexicano del Seguro Social. Guía técnica para otorgar atención médica en el módulo DiabetIMSS a derechohabientes con diagnósticos de diabetes mellitus, en Unidades de Medicina Familiar. México: IMSS; 2009.

23. Sandín M, Espelt A, Escolar-Pujolar A, et al. Desigualdades de género y diabetes mellitus tipo 2: la importancia de la diferencia. Av Diabetol. 2011;27:78-87.

24. Dávila-Cervantes CA, Agudelo-Botero M, Gloria-Hernández LE. Diabetes en México y Colombia: análisis de la tendencia de años de vida perdidos. Rev Salud Pública. 2011;13:560-71.

25. Davila C, Pardo A. Diabetes mellitus: aporte al cambio en esperanza de vida en México 1990, 2000 y 2010. Rev Salud Pública. 2014; 16:910-23.

26. Escobedo de la Peña J, Reinoso J, Flores L, et al. Encuesta nacional del tratamiento y control metabólico y de los factores de riesgo cardiovascular de los pacientes con diabetes mellitus tipo 2, atendidos por especialistas en medicina interna. Med Int Mex. 2010;26:449-56.

27. Estadísticas de mortalidad en México: muertes registradas en el año 2001. Salud Pública Méx. 2002;44:565-81.

28. Hernández $B$, Ramírez-Villalobos $D$, Romero $M$, et al. Assessing quality of medical death certification: concordance between gold standard diagnosis and underlying cause of death in selected Mexican hospitals. Popul Health Metr. 2011;9:38.

29. Regidor E, Guallar-Castillón P, Gutiérrez-Fisac JL, et al. Socioeconomic variation in the magnitude of the association between self-rated health and mortality. Ann Epidemiol. 2010;20:395-400.

30. Saydah S, Lochner K. Socioeconomic status and risk of diabetes-related mortality in the U.S. Public Health Rep. 2010;125:377-88.

31. Jaffiol C, Thomas F, Bean K, et al. Impact of socioeconomic status on diabetes and cardiovascular risk factors: results of a large French survey. Diabetes Metab. 2013;39:56-62. 